\title{
MEMAHAMI SECARA KRITIS PEMIDANAAN \\ DALAM UNDANG-UNDANG PERBANKAN
}

Oleh:

Dr. Faisal, S.H., M.H.*

Email: progresif_1shp@yahoo.com

\begin{abstract}
General Purpose of punishment in criminal law at least can be divided into two : first, this goal patterned conceptual gave basis of criminal sanctions, the type and form of criminal sanction. Second, the purpose of criminal sanctions against those who violate the criminal law. In the banking law, not explicitly mentioned purpose of criminal sanctions in specific meaning. But can be seen in the banking law has only a more general purpose.
\end{abstract}

Keyword: Banking Law, Punishment, Criminal Sanctions, Criminalization

\section{A. PENDAHULUAN}

Perbankan ialah salah satu subsistem dari industri jasa keuangan. Dalam aktivitas perbankan selain sebagai media akumulasi modal dari masyarakat untuk disalurkan dalam bentuk kredit pada berbagai industri, aktivitas perbankan juga dianggap sebagai motor penggerak prekonomian suatu negara. Sifat modal disini tidak saja di artikan dalam bentuk uang akan tetapi sifat modal yang utama bertumpu pada hal pengelolaan kepercayaan yang diberikan masyarakat. Karena kepercayaan masyarakat pada aktivitas perbankan adalah pelayanaan yang menjadi proiritas utama. Jika sebaliknya, maka ketidakpercayaan dapat menjadikan aktivitas perbankan tersebut menjadi ambruk dalam waktu sekejab. ${ }^{1}$

Dari apa yang dikemukakan di atas terlepas dari faktor iklim ekonomi yang mempengaruhi aktivitas perbankan, bahwa korelasi antara pengaturan perbankan dengan aktivitas perbankan itu sendiri mempunyai peran yang sangat penting. Pengaturan perbankan melalui peraturan perundangundangan tentunya memiliki tujuan melindungi fungsi perbankan dalam perekonomian negara. Lebih khusus

*Dosen Tetap Fakultas Hukum Universitas Bangka Belitung

${ }^{1}$ Lash mengatakan dalam kurun waktu abad ke-19 hingga memasuki abad ke-20 di Amerika Serikat setiap 20 tahun sekali terjadi krisis perbankan sebagai akibat dari ketidakpercayaan masyarakat pada perbankan nasionalnya. Hikmahanto Juwana, 2001, Bunga Rampai Hukum Ekonomi dan Hukum Internasional, Jakarta, Lentera Hati, hlm. 04. 
lagi dengan adanya pengaturan mengenai perbankan dapat menjaga keamanan bank, memungkinkan terciptanya iklim kompetisi, perlindungan terhadap nasabah dan menciptakan suasana yang kondusif bagi pengambil kebijakan moneter. ${ }^{2}$

Indonesia mengalami sejarah yang pasang surut dalam melakukan pengaturan megenai perbankan. Dalam kurun waktu sejak Indonesia merdeka hingga saat ini, telah banyak produk hukum yang mengatur dunia perbankan. Produk hukum pertama yang mengatur aktivitas perbankan adalah Peraturan Pemerintah Penganti Undang-Undang (Perpu) No. 02/1946 yang menegaskan kelahiran BNI kemudian pada tahun 1953 dikeluarkan Undang-Undang No. 11/1953 Tentang Penetapan UU Pokok Bank Indonesia. Selanjutnya mengalami perubahan dengan dikeluarkannya UU No. 13/1968 Tentang Bank Sentral. ${ }^{3}$

Di samping itu peraturan perundang-undangan yang sangat penting dalam mengatur aktivitas perbankan adalah UU No.14/1967 Tentang Pokok-Pokok Perbankan kemudian dicabut pada tahun 1992

\footnotetext{
${ }^{2}$ Hikmahanto Juwana, Bunga Rampai....Op., Cit, hlm. 05 .

${ }^{3}$ Ibid
}

dan digantikan dengan UU No. 7/1992

Tentang Perbankan dan terakhir telah mengalami perubahan kembali berdasarkan Undang-Undang No. 10/1998. Pengaturan mengenai perbankan bisa juga kita lihat pada Undang-Undang No. 23/1999 Tentang Bank Indonesia.

Pengaturan mengenai perbankan yang terus menerus mengalami perubahan menunjukkan bahwa ruang lingkup persoalan perbankan tidak hanya dapat diselesaikan pada aspek analisa ekonomi saja. Diperlukan instrumen hukum sebagai mekanisme lalu lintas perbankan. Artinya, peraturan perbankan yang berlaku saat ini diharapkan dapat meminimalisasi tindak pidana di bidang perbankan. Sehubungan dengan tindak pidana perbankan tersebut, bahwa dalam UU No. 10/1998 dan UU No. 23/1999 memiliki pengertian dan ruang lingkup sistem pemidanaan tersendiri.

Maka ketentuan sistem pemidanaan perbankan merupakan bagian khusus (subsistem) dari keseluruhan sistem pemidanan. Ini berarti sistem pemidanaan perbankan harus terintegrasi dalam (konsisten dengan) aturan umum (Buku I KUHP), namun dapat juga membuat aturan khusus (UU Khusus di luar KUHP) yang berbeda dengan aturan umum. Lebih 
lanjut pada bagian berikutnya akan lebih difokuskan mengidentifikasi ketentuan sistem pemidanaan khususnya dalam UU No. 10/1998 tentang perbankan dan UU No. 23/1999 tentang Bank Indonesia yang meliputi; kualifikasi tindak pidana, subjek dan pertanggungjawaban pidana, perumusan dan jenis sanksi pidana, jumlah/lamanya pidana serta aturan pemidanaan.

\section{B. PEMBAHASAN}

\section{Pidana dan Pemidanaan Dalam}

\section{Undang-Undang Perbankan}

Di antara bagian dari hukum pidana selain mengatur masalah perbuatan yang dilarang (perbuatan pidana), masalah pemidanaan merupakan masalah yang paling urgen dalam hukum pidana. Masalah pemidanaan juga tidak dapat dilepaskan dari ketentuan tentang tujuan pemidanaan. Karena masuknya tujuan pemidanaan ke dalam undang-undang perbankan akan menjadi dasar hukum dan sekaligus sebagai parameter pencapaian tujuan dalam menjatuhkan sanksi pidana.

Oleh sebab itu membicarakan masalah pemidanaan tidak dapat dilepaskan dari filsafat hukum pidana, politik (kebijakan) hukum pidana (dan kebijakan sosial), filsafat pemidanaan (dan kebijakan kriminal). Kajian yang mendalam dan komprehensif mengenai masalah pemidanaan sangat diperlukan, agar hukum pidana dan penegakan hukum pidana nantinya dapat menyentuh rasa keadilan masyarakat yang umumnya menjadi target pelanggar hukum pidana dan pihak yang menderita kerugian (materiil dan immateriil). ${ }^{4}$

Hulsman pernah mengemukakan, bahwa sistem pemidanaan (the sentencing system) adalah "aturan perundangundangan yang berhubungan dengan sanksi pidana dan pemidanaan" (the statutory rules relating to penal sanctions and punishment). Apabila pengertian pemidanaan diartikan secara luas sebagai suatu proses pemberian atau penjatuhan sanksi pidana oleh hakim, maka dapatlah dikatakan bahwa sistem pemidanaan mencakup pengertian keseluruhan sistem (aturan perundang-

\footnotetext{
4 Mudzakkir, Kajian Terhadap Ketentuan Pemidanaan Dalam Draf RUU KUHP, Makalah disampaikan pada Sosialisasi Rancangan Kitab Undang-Undang Hukum Pidana yang diselenggarakan oleh Direktorat Jenderal Peraturan Perundang-Undangan Departemen Kehakiman dan HAM RI, Jakarta 29 Juli 2004, hlm. 1-2.
} 
undangan) yang meliputi: pemidanaan, pemberian/penjatuhan dan pelaksanaan pidana, fugsionalisasi/konkritisasi pidana, dan operasionalisasi secara konkrit penjatuhan sanksi pidana. ${ }^{5}$

Dengan pengertian demikian, maka semua aturan perundangundangan mengenai hukum pidana materiel/subtantif, hukum pidana formal dan hukum pelaksanaan pidana dapat dilihat sebagai satu kesatuan sistem pemidanaan. Dengan kata lain, sistem pemidanaan terdiri dari subsistem hukum pidana subtantif, subsistem hukum pidana formal, dan subsistem hukum pelaksanaan/ eksekusi pidana. ${ }^{6}$

Bertolak dari pengertian di atas, apabila dibatasi pada hukum pidana subtantif, maka keseluruhan sistem peraturan perundang-undangan yang ada di dalam KUHP sebagai induk aturan umum. Kemudian Undang-undang khusus di luar KUHP, pada hakikatnya merupakan satu kesatuan sistem pemidanaan subtantif. Keseluruhan peraturan perundang-undangan di

5 Muladi \& Barda Nawawi Arief, 2005, TeoriTeori dan Kebijakan Pidana, Bandung, Alumni, hlm. 135.

6 Muladi \& Barda Nawawi Arief, TeoriTeori....Op., Cit, hlm. 136-137. bidang hukum pidana subtantif itu, terdiri dari "aturan umum" dan "aturan khusus". Aturan umum terdapat di dalam KUHP (Buku I), dan aturan khusus terdapat di dalam KUHP (Buku II dan Buku III) maupun dalam Undang-undang khusus di luar KUHP. Aturan khusus ini pada umumnya memuat perumusan tindak pidana tertentu, namun dapat pula memuat aturan khusus yang berada di luar dari aturan umum. ${ }^{7}$

Salah satu aturan khusus yang berada di luar KUHP, ialah pengaturan mengenai perbankan, khususnya pada UU No. 10/1998 dan UU No.23/1999. Beberapa hal penting yang dapat diidentifikasi terhadap sistem pemidanaan undang-undang perbankan yang memiliki persamaan dan perbedaan, dapat kita lihat pada UU No.10/1998 tentang perbankan dan UU No.23/1999 tentang Bank Indonesia. Setidaknya persamaan ini ditunjukkan pada jenis sanksi pidana hanya mencantumkan pidana pokok berupa penjara/kurungan dan denda (tidak ada pidana tambahan maupun sanksi tindakan), terdapat sanksi 
administratif (tetapi sanksi ini tidak di integrasikan ke dalam sistem pemidanaan sebagai pidana tambahan atau tindakan), serta sanksi pidana penjara/kurungan dan denda dirumuskan secara kumulatif dan dengan sistem minimal khusus.

Kemudian perbedaan tampak juga dari sanksi pidana denda yang secara nominal berbeda (UU No.10/1998 tentang perbankan sanksi pidana denda dijatuhkan mulai dari "satu miliar rupiah" sampai dengan "dua ratus miliar rupiah", sedangkan pada UU No 23/1999 tentang bank Indonesia hanya "lima puluh juta rupiah" sampai dengan "lima belas miliar rupiah"), kedua undang-undang tersebut sama-sama mengatur subjek tindak pidana berupa badan hukum (perbedaanya hanya berada pada ruang lingkup jabatan, perintah dan perbuatan dalam hal pertanggungjawaban pidananya), serta dalam UU No.10/1998 mencantumkan kualifikasi delik sebagai "kejahatan" dan "pelanggaran" dan sebaliknya pada UU No.23/1999 tidak ada kulifikasi deliknya.

Paling tidak dari beberapa hal yang diuraikan di atas dapat mengantarkan kita untuk lebih lanjut melakukan analisis terhadap ketentuan pemidanaan pada undang-undang perbankan. Sehingga kita dapat melihat sejauh mana efektifitas ketentuan sistem pemidanaan pada undang-undang perbankan dapat mencapai penegakan hukum di bidang perbankan. Tentu hal ini sangat tergantung dengan ruang lingkup sanksi pidana (pemidanaan) berdasarkan pertimbangan kebijakan yang rasional.

\section{Relevansi Tindak Pidana} Perbankan dan Upaya Kriminalisasi

Relevansi dalam hal ini di maknai sebagai upaya menggiring tindak pidana di bidang perbankan kedalam proses kriminalisasi. Kriminalisasi diartikan sebagai penentu suatu perbuatan yang awalnya bukan merupakan perbuatan yang dilarang kemudian menjadi perbuatan yang dilarang (melawan hukum) disertai juga ancaman sanksinya. Disamping itu, kriminalisasi juga terkait dengan penambahan/peningkatan sanksi pidana terhadap tindak pidana yang sudah ada. ${ }^{8}$

\footnotetext{
8 Salman Luthan dalam Kebijakan Penal mengenai Kriminalisasi di Bidang Keuangan
} (Studi Terhadap Pengaturan Tindak Pidana dan 
Berdasarkan pengertian kriminalisasi tersebut, terdapat beberapa kriteria perlunya suatu perbuatan tertentu dapat dikriminalisasikan, antara lain: (1) Penggunaan hukum pidanaharus memperhatikan tujuan pembangunan nasional yaitu mewujudkanmasyarakat adil dan makmur yang merata secara materiil dan spirituil berdasarkan falsafah bangsa ini, yaitupancasila. Kemudian yang ke (2) Perbuatan yang diusahakan untuk dicegah atau ditanggulangidengan hukum pidana harus merupakan perbuatan yang tidak di kehendakiyaitu perbuatan yang mendatangkan kerugian (materiil dan atau spiritual) bagiwarga masyarakat; (3) Penggunaan hukum pidana harus pula memperhitungkanprinsip biaya dan hasil (cost and benefit principle);(4)Penggunaan hukum pidanaharus pula memperhatikan kapasitas atau kemampuan daya kerja dari badan-badanhukum yaitu

Sanksi Pidana dalam Undang-undang Perbankan, Perpajakan, Pasar Modal dan Pencucian Uang), Disertasi Program Doktor Program Pascasarjana Fakultas Hukum Universitas Indonesia, Jakarta, 2007, hlm. 54. jangan sampai ada kemampuan beban tugas (overbelasting). ${ }^{9}$

Dari pertimbangan tersebut di atas maka alasan kriminalisasi pada umumnya meliputi; adanya korban, kriminalisasi tidak semata-mata untuk tujuan pembalasan, harus berdasarkan asas ratio principle, dan adanya kesepakatan sosial (public support). ${ }^{10}$

Alasan yang menyebutkan adanya korban ini menyiratkan bahwa perbuatan tersebut harus menimbulkan sesuatu yang buruk atau menimbulkan kerugian. Jika, alasan ini kemudian di hubungkan dengan tindak pidana perbankan, maka kerugian yang akan ditimbulkan sangat problematik. Tindak pidana di bidang perbankan adalah tindak pidana yang merugikan kepentingan berbagai pihak, baik bank itu sendiri selaku badan usaha, nasabah penyimpan dana, sistem perbankan, otoritas perbankan, negara dan pemerintah, serta masyarakat luas. Disamping itu tindak pidana perbankan tersebut dapat menurunkan tingkat kepercayaan masyarakat terhadap dunia perbankan, juga

\footnotetext{
9 Teguh Prasetyo \& Abdul Halim Barkatullah, 2005, Politik Hukum Pidana, Yogyakarta, Pustaka Pelajar, hlm. 51.

${ }^{10}$ Ibid
} 
menimbulkan kerugian finansial yang cukup besar jumlahnya secara kumulatif. $^{11}$

Berdasarkan kerugian yang dapat ditimbulkan dari tindak pidana di bidang perbankan, sehingga sangat wajar ketika negara melakukan upaya kriminalisasi terhadap tindak pidana perbankan. Kemudian, lebih jauh kedepan timbul suatu pertanyaan apakah dasar negara untuk mengkualifikasikan tindak pidana perbankan sebagai perbuatan kriminal?

Dalam berbagai macam teoriteori kriminalisasi yang hadir, setidaknya dapat memberikan pertimbangan secara rasional dalam menetapkan kebijakan kriminal. Dasar pembenar untuk melakukan upaya kriminalisasi terhadap tindak pidana di bidang perbankan adalah berdasarkan teori liberal individualistik. Sebagaimana di ungkapkan oleh Jhon Stuart Mill, bahwa negara mempunyai kewenangan untuk mengatur masyarakatnya, akan tetapi dalam hal ini kewenangan tersebut juga dibatasi oleh kebebasan warga

11 Wahyuni Bahar, 2007, Tindak Pidana di Bidang Perbankan, Jakarta, Centre for Finance, Investment and Securities Law (CFISEL), hlm. 24. negaranya. Artinya, asumsi dasar dari teori liberal individualistik ini, bahwa negara hanya boleh campur tangan terhadap kehidupan pribadi warga negaranya, bila warga negaranya tersebut merugikan kepentingan orang lain. Jika tindakan seseorang tidak merugikan orang lain, maka tidak boleh ada pembatasan terhadap kebebasannya. Artinya teori liberal individualistik mengatakan, bahwa perilaku jahat dapat dicegah jika negara memberikan sanksi/hukuman kepada seseorang yang merugikan kepentingan orang lain. $^{12}$

Di samping menggunakan teori liberal individualistik, dasar pembenaran kriminalisasi bagi tindak pidana di bidang perbankan juga dapat menggunakan teori ordenings strafrecht. Tesis pokok dari teori ini, bahwa suatu perbuatan dapat dikriminalisasikan menjadi tindak pidana karena bertentangan dengan kebijakan pemerintah. ${ }^{13}$ Relevansi tesis pokok teori ini sangat berpengaruh sekali dengan perkembangan prekonomian suatu negara yang

\footnotetext{
12 Salman Luthan, dalam Kebijakan....Op., Cit, hlm. 437.

${ }^{13}$ Ibid.
} 
menjadi kebijakan pemerintah. Artinya, jika terjadi tindak pidana di bidang perbankan maka salah satunya akan berdampak buruk terhadap iklim ekonomi setiap negara.

Dengan demikian, teori liberal individualistik dan teori ordenings strafrecht dapat digunakan sebagai dasar pembenar untuk mengkriminalisasikan tindak pidana di bidang perbankan yang di ancam dengan sanksi pidana tertentu.

\section{Telaah Kritis Terhadap Pidana} dan Pemidanaan UndangUndang Perbankan

Dalam hukum pidana setidaknya tujuan pemidanaan secara umum dapat dibedakan menjadi dua yaitu; pertama, tujuan ini bercorak konseptual yang memberi dasar adanya sanksi pidana, jenis dan bentuk sanksi pidana. Kedua, tujuan dalam penjatuhan sanksi pidana terhadap orang yang melanggar hukum pidana. Tujuan yang terakhir ini bercorak pragmatik dengan ukuran-ukuran yang lebih jelas dan konkret serta relevan dengan problem yang muncul akibat adanya pelanggaran hukum pidana dan orang yang melakukan pelanggaran hukum pidana. ${ }^{14}$

Dalam undang-undang perbankan, tidak disebutkan secara eksplisit tujuan pemidanaan dalam arti yang lebih khusus. Namun dapat dilihat dalam undang-undang perbankan hanya memiliki tujuan yang lebih umum, secara tegas mengatur hal-hal yang dianggap sebagai tindak pidana di bidang perbankan sebagaimana diatur dalam Pasal 46 sampai dengan Pasal 50 UU No.10 Tahun 1998 tentang perbankan yang secara garis besarnya dapat dikelompokkan mejadi beberapa jenis, yaitu;

a. Tindak pidana yang berkaitan dengan perizinan (Pasal 46 jo Pasal 16). Hal ini mengingat dalam kegiatan dalam kegiatan di bidang perbankan terkait dengan perlindungan dana masyarakat yang disimpan di bank, sehingga setiap pihak yang menghimpun dana masyarakat wajib terlebih dahulu memperoleh izin sebagai bank dari Bank Indonesia. Jika prosedur ini tidak dipenuhi, maka pihak terkait disebut

14 Bambang Waluyo, 2004, Pidana dan Pemidanaan, Jakarta, Sinar Grafika, hlm. 35. 
sebagai "bank gelap" yang dapat diancam dengan pidana penjara sekurang-kurangnya 5 tahun dan paling lama 15 tahun serta denda sekurang-kurangnya $\quad \mathrm{Rp} \quad 10$ miliar dan paling banyak 200 miliar.

b. Tindak pidana yang berkaitan dengan rahasia bank (Pasal 40, 41, 41A, 42A, 43, 44, 44A, 45, $47 \& 47 A)$. Ketentuan rahasia bank diperlukan untuk menjaga kepercayaan

masyarakat/nasabah terhadap bank yang bersangkutan. Untuk itu maka bagi pihak yang melanggar ketentuan rahasia bank perlu diberikan sanksi pidana.

c. Tindak pidana yang berkaitan dengan pengawasan bank oleh Bank Indonesia (Pasal 29, 30 \& 48).

d. Tindak pidana yang berkaitan dengan kegiatan usaha bank (Pasal 49 ayat $1 \& 2$ ).

e. Tindak pidana yang terkait dengan pihak terafiliasi (Pasal 50). Undang-undang perbankan tidak hanya mengatur kewajiban pengurus dan pegawai bank, tetapi juga pihak yang terafiliasi yang meliputi; akuntan publik, konsultan hukum, pemegang saham dan keluarga pengurus bank.

f. Tindak pidana yang terkait dengan pemegang saham (Pasal $50 \mathrm{~A})^{15}$

Selanjutnya berdasarkan ketentuan-ketentuan di atas, dapat disimpulkan bahwa ruang lingkup tindak pidana di bidang perbankan sebagaimana diatur dalam Pasal 46 sampai dengan 50A UU No.10/1998 tentang perbankan, adalah menggunakan bank baik sebagai sarana ataupun sasaran dalam tindak pidana namun tidak tertutup pula kemungkinan dikenakan ketentuan-ketentuan pidana sebagaimana diatur dengan perundang-undangan lainnya. ${ }^{16} \mathrm{Hal}$ yang dimaksud berada pada UU No.23/1999 tentang bank Indonesia, dalam undang-undang ini juga mengatur mengenai tindak pidana dan sanksi pidana perbankan sebagaimana terdapat pada Pasal 65, 66, 67, 68, 69, 70 ayat (1) \& (2), 71 ayat (1) \& (2), dan 72 ayat (1). ${ }^{17}$

Adanya ketentuan tentang tujuan pemidanaan dalam undang-undang

\footnotetext{
${ }^{15}$ Wahyuni Bahar, Tindak Pidana...Op., Cit, hlm. 8-10.

${ }^{16} \mathrm{Ibid}$.

17 Undang-Undang Nomor 23 Tahun 1999 Tentang Perbankan.
} 


\begin{abstract}
perbankan dalam arti yang lebih umum sebagaimana telah dijelaskan di atas, dapat dikemukakan pada bagian ini beberapa catatan-catatan penting yang terkait erat dengan sistem pemidanaan perbankan dalam UU No.10/1998 tentang perbankan yang dapat disingkat (UUP) dan dalam UU No.23/1999 tentang bank Indonesia (UUB), dapat diberikan catatan sebagai berikut;
\end{abstract}

a. Masalah Kualifikasi Tindak Pidana

$$
\text { Seperti yang sudah }
$$
disebutkan didepan, bahwa ada perbedaan sikap mengenai kualifikasi delik dalam (UUP) dan (UUBI). Jika pada undangundang perbankan (UUP) disebutkan kualifikasi deliknya "kejahatan" dan "pelanggaran" (dalam Pasal 51), sebaliknya dalam undang-undang bank Indonesia (UUBI) sama sekali tdak mencantumkan kualifikasi deliknya secara tegas. ${ }^{18}$

Jadi fungsi untuk menetapkan kualifikasi delik itu adalah untuk menjembatani berlakunya aturan umum KUHP terhadap hal-hal

18 Barda Nawawi Arief, 2003, Kapita Selekta Hukum Pidana, Bandung, Citra Aditya Bakti, hlm. 140. yang diatur dalam undangundang diluar KUHP. Dapat disimpulkan kualifikasi delik dalam (UUBI) secara tegas harus disebutkan, salah satunya hal ini terkait dengan hapusnya kewenangan penuntutan pidana karena daluwarsa. Karena di dalam Buku I KUHP (aturan umum) mengatur kewenangan menuntut pidana hapus karena daluwarsa (Pasal $78 \& 84$ ), dan penentuan itu berdasarkan kulifikasi deliknya "pelanggaran" atau "kejahatan" mendapat tingkat ketentuan yang berbeda-beda. Artinya dalam hal ini, bagaimana bisa dalam undang-undang di luar KUHP ingin menentukan daluwarsa ketika tidak menyebutkan secara tegas kualifikasi deliknya. Maka jika dilihat undang-undang perbankan pada konteks ini mengandung kelemahan dan sekiranya tidak dapat berjalan efektif.

b. Masalah subjek tindak pidana dan pertanggungjawaban pidana korporasi

Dalam undang-undang perbankan (UUP) dan undangundang bank Indonesia (UUBI) 
ada subjek tindak pidana berupa "korporasi" yang dalam kedua undang-undang itu disebutkan dengan istilah "badan hukum", ${ }^{19}$ (perbedaanya hanya berada pada ruang lingkup jabatan, perintah dan perbuatan dalam hal pertanggungjawaban pidananya).

Dari uraian di atas terlihat, bahwa kedua undang-undang tersebut tidak konsisten dalam mengatur masalah siapa yang dapat dituntut dalam hal delik yang dilakukan korporasi. Kelemahan lain adalah tidak adanya ketentuan mengenai kapan/dalam hal apa korporasi itu dikatakan telah berbuat atau melakukan tindak pidana, kemudian kapan korporasi itu dapat dipertanggungjawabkan. Beberapa catatan tersebut sejogjanya harus dijelaskan lebih lanjut dalam undangundang perbankan.

c. Perumusan sanksi pidana administratif

Walaupun kedua undangundang tersebut mencantumkan sanksi administratif, namun sanksi administratif tersebut tidak diintegrasikan ke dalam sistem pemidanaan, walaupun ada diantaranya yang dapat dikategorikan sebagai pidana tambahan atau tindakan. Dengan tidak diintegrasikannya sanksi administratif ke dalam sistem pemidanaan, memberi kesan kuat bahwa pembuat undangundang masih membedakan antara sanksi pidana dan sanksi administratif. $^{20}$

d. Jenis Pidana

Di dalam kedua undangundang tersebut mencantumkan pidana pokok berupa pidana penjara/kurungan dan denda yang kebanyakan dirumuskan secara kumulatif, kemudian terdapat juga pidana tambahan. Akan tetapi jenis-jenis pidana tersebut lebih berorientasi pada "offender" (baik berupa "orang" maupun "korporasi"). Belum tampak jenis pidana yang berorientasi pada korban, seperti misalnya ganti rugi (restitusi/kompensasi). Oleh karena itu, patut pula dipertimbangkan adanya pidana ganti rugi.

e. Masalah jumlah/lamanya pidana 
Di dalam undang-undang perbankan (UUP) dan undangundang bank Indonesia (UUBI) dianut sistem pidana minimal khusus, tetapi tidak diikuti dengan aturan/pedoman penerapannya. Dengan dianutnya sistem minimal khusus yang menyimpang dari sistem KUHP, maka seharusnya undang-undang khusus di luar KUHP membuat aturan khusus/tersendiri untuk penerapannya. $^{21}$

Dari beberapa catatan di atas terdapat barbagai masalah/ kelemahan kebijakan formulasi dalam sistem pemidanaan perbankan. Perlu kiranya dalam menentukan kebijakan kriminal di sandarkan pada orientasi pendekatan nilai dan pendekatan yang rasional. Maka perlu diupayakan reorientasi dan re-evaluasi terhadap masalah-masalah yang berhubungan dengan pidana dan pemidanaan dalam undang-undang perbankan. Inilai kiranya yang menjadi masalah pokok yang perlu ditinjau kembali secara kritis.

\section{PENUTUP}

$\begin{array}{ccr}\text { Sebagai } & \text { kesimpulan } & \text { dapat } \\ \text { dikemukakan } & \text { beberapa } & \text { catatan }\end{array}$

penting; pertama, bahwa dalam undang-undang perbankan baik itu pada (UUP) dan (UUBI) belum mencantumkan tujuan pemidanaan secara khusus, artinya dianggap perlu menyebutkan tujuan pemidanaan secara lebih khusus. Kedua, harus ada penegasan kualifikasi delik secara eksplisit; ketiga, mengenai pertanggunjawaban pidana yang menjadi subjek hukum pidana ialah korporasi, bahwa perlu ada penegasan korporasi dapat dipidana kapan (dalam hal bagaimana) korporasi dikatakan telah melakukan tindak pidana serta kapan korporasi dapat dikatakan bertanggungjawab. Keempat, perumusan jenis sanksi pidana seyogianya berorientasi pada pelaku dan korban; dan kelima, perlu di buat aturan/pedoman penerapan sanksi pidana minimal khusus dan pelaksanaan pidana denda. Keenam, sanksi administratif diintegrasikan kedalam sistem pemidanaan (sebagai pidana tambahan atau tindakan).

\section{DAFTAR PUSTAKA}

Arief Nawawi Barda, 2003, Kapita Selekta Hukum Pidana, Citra Aditya Bakti, Bandung.

\begin{tabular}{lrr} 
& $\&$ & Muladi, \\
\hline 2005, & Teori-Teori & dan \\
Kebijakan & Pidana, & Bandung, \\
Alumni. &
\end{tabular}


Barkatullah Halim Abdul \& Prasetyo Teguh, 2005, Politik Hukum Pidana, Yogyakarta, Pustaka Pelajar.

Bahar Wahyuni, 2007, Tindak Pidana di Bidang Perbankan, Jakarta, Centre for Finance, Investment and Securities Law (CFISEL).

Juwana Hikmahanto, 2001, Bunga Rampai Hukum Ekonomi dan Hukum Internasional, Jakarta, Lentera Hati.

Luthan Salman, Kebijakan Penal mengenai Kriminalisasi di Bidang Keuangan (Studi Terhadap Pengaturan Tindak Pidana dan Sanksi Pidana dalam Undang-undang Perbankan, Perpajakan, Pasar Modal dan Pencucian Uang), Disertasi Program Doktor Program Pascasarjana Fakultas Hukum Universitas Indonesia, Jakarta, 2007.

Mudzakkir, Kajian Terhadap Ketentuan Pemidanaan Dalam Draf RUU KUHP, Makalah disampaikan pada Sosialisasi Rancangan Kitab UndangUndang Hukum Pidana yang diselenggarakan oleh Direktorat Jenderal Peraturan PerundangUndangan Departemen Kehakiman dan HAM RI, Jakarta 29 Juli 2004.

Waluyo Bambang, 2004, Pidana dan Pemidanaan, Jakarta, Sinar Grafika. 